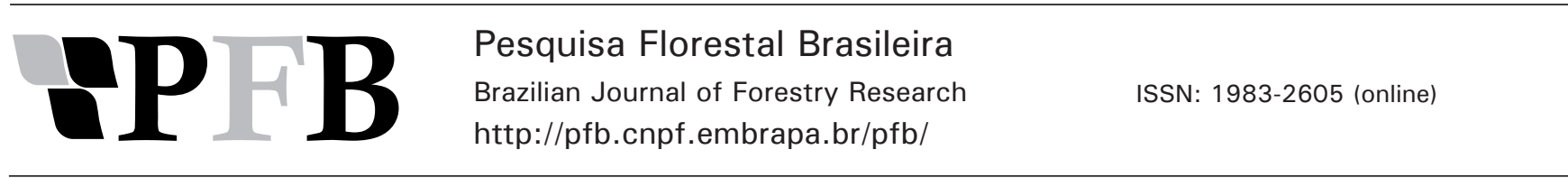

\title{
Strategies of two tropical woody species to tolerate salt stress
}

Bruno Melo Lustosa ${ }^{1}$, Lígia Gomes Ferreira de Souza1 , Gabriella Frosi ${ }^{*}$, Hiram Marinho Falcão ${ }^{1}$, Silvia Pereira ${ }^{1}$, Marciel Teixeira Oliveira ${ }^{1}$, Mauro Guida Santos ${ }^{1}$

${ }^{1}$ Universidade Federal de Pernambuco, Av. Professor Moraes Rêgo, 1235, CEP 50670-901, Recife, PE, Brasil

*Autor correspondente:

gabriella.frosi@gmail.com

Index terms:

Biochemical analysis

Leaf gas exchange

Leaf water potential

Termos para indexação:

Análises bioquímicas

Trocas gasosas foliares

Potencial hídrico foliar

Histórico do artigo:

Recebido em 12/08/2016

Aprovado em 23/03/2017

Publicado em 31/03/2017

doi: 10.4336/2017.pfb.37.89.1332

\begin{abstract}
This study aimed to evaluate the leaf primary metabolism in two woody species, Sterculia foetida and Bombacopsis glabra. Both species have seeds rich in oil and they are largely found in regions with irregularities in water availability. Seedlings were grown in a greenhouse from seeds. At 140 days after emergence, 50\% of the plants were subjected to salt stress for 23 days, daily receiving $100 \mathrm{mM}$ of $\mathrm{NaCl}$ solution. In both species, leaf stomata conductance and water potential decreased quickly under salt stress. The two species showed different strategies in photosynthetic pigment concentration and components of nitrogen metabolism. S. foetida kept the pigment concentration unchanged after 23 days of stress, while $B$. glabra increased concentration of chlorophyll $a$ and carotenoids. $S$. foetida showed a high leaf concentration of $\mathrm{K}^{+}$in stressed plants and a $\mathrm{Na}^{+} / \mathrm{K}^{+}$ratio without differences when compared to control. Thus, $S$. foetida presented a better ionic balance, while $B$. glabra invested in photoprotection. Therefore, both species present potential to be planted in Brazilian Northeast, where water deficit and salt stress are challenging for annual crops.
\end{abstract}

\section{Estratégias para tolerar o estresse salino em duas espécies lenhosas tropicais}

Resumo - O estudo teve como principal objetivo avaliar o metabolismo primário foliar de duas espécies lenhosas, Sterculia foetida e Bombacopsis glabra, de sementes ricas em óleo e amplamente encontradas em regiões com disponibilidade hídrica irregular. As duas espécies foram cultivadas em casa de vegetação a partir de sementes. Aos 140 dias após a emergência, $50 \%$ das plantas foram submetidas ao estresse salino durante 23 dias, recebendo diariamente uma solução de $100 \mathrm{mM}$ de $\mathrm{NaCl}$. As duas espécies rapidamente reduziram a sua condutância estomática e o potencial hídrico foliar, em relação às plantas controle. S. foetida e B. glabra apresentaram estratégias diferentes quanto ao conteúdo de pigmentos fotossintéticos e componentes do metabolismo do nitrogênio. S. foetida manteve seus pigmentos intactos após 23 dias de estresse, enquanto B. glabra aumentou o conteúdo de clorofila $a$ e carotenoides. $S$. foetida apresentou alto teor foliar de $\mathrm{K}^{+}$e uma relação $\mathrm{Na}^{+} / \mathrm{K}^{+}$sem diferença nas plantas estressadas comparadas com as do controle. Portanto, S. foetida apresentou um melhor em balanço iônico, enquanto B. glabra investiu em fotoproteção. Assim, as duas espécies são alternativa potencial para serem cultivadas no Nordeste brasileiro, onde condições de estresse hídrico e salinidade são restritivas para culturas anuais. 


\section{Introduction}

In semiarid and arid areas, soil salinization is a common situation (FAO, 2009; Janz \& Polle, 2012). In dry hot areas, the significant evapotranspiration of the soil transports salt to surface layers, leading to an accumulation of salt at toxic concentrations (Polle \& Chen, 2015). In Brazilian Northeast region, it is estimated that approximately $30 \%$ of irrigate areas have saline soils (Aguiar Neto et al., 2007). Salinity levels of soils, associated with a low and irregular rainfall characteristic of this region (Santos et al., 2014), make it marginalized and regarded areas unfit for cultivation.

Saline soils contain high concentrations of $\mathrm{Na}^{+}$(Polle \& Chen, 2015). Responses to salt follow a biphasic model: the first phase generates reduction of water uptake by roots, leading to a slower growth, similar to drought response; the second phase results in toxic effects of salt inside the plant (Munns et al., 2006; Chaves et al., 2009). Salt stress has a multilevel effect on the plant, leading to changes in its physiology, morphology, biochemistry and molecular responses (Polle \& Chen, 2015). Direct effects of salt on plant growth may involve reduction in osmotic potential of the soil solution (Jahromi et al., 2008), and toxicity from the excess of $\mathrm{Na}^{+}$and $\mathrm{Cl}^{-}$ ions towards the cell. Toxic effects include disruption of enzymes structure and of other macromolecules (Feng et al., 2002). Furthermore, salinity stress could promote nutrient imbalance caused by depletion in the nutrient uptake and/or transport to shoot, leading to ion deficiencies (Munns \& Tester, 2008).

Semiarid and arid areas around the world are subject to changes, as shown under the current global climate change scenario, which predicts the rise in air temperature and irregular rainy regimes in consequence of high $\mathrm{CO}_{2}$ emission promoted by anthropogenic activities (Pachauri $\&$ Meyer, 2014). The use of alternative and sustainable energy sources is proving to be an important mitigating factor of these effects. In this context, the replacement of fossil fuels for biofuel is becoming a factor that improves the energy sector and the raw material production system (Mathur \& Vyas, 2013).

The first challenge to use marginalized areas for food production, as saline soils and irregular rainfall regimes is to choose tolerant species. Some woody species have showed adaptation to semiarid or arid conditions (Janz \& Polle, 2012). Thus, the aim of this study was to evaluate the effects of salinity on the physiological characteristics and leaf biochemical metabolism of two tree species, Bombacopsis glabra (Pasq.) A. Robyns and Sterculia foetida L., found in a wide area in Northeast of Brazil. We measured leaf photosynthetic machinery characteristics and the primary biochemical metabolism of leaves after 23 days under salt stress and non-salt stress (control) conditions, to verify if both species are tolerant to salinity.

\section{Material and methods}

Bombacopsis glabra and Sterculia foetida belong to Malvaceae family. They are found in semiarid region of Northeast Brazil and they are used in recovery programs for degraded areas (Chaves et al., 2012; Santos et al., 2004). S. foetida occurs from East Africa to North Australia (Bindhu et al., 2012) and it is well adapted to tropical and sub-tropical areas (Silitonga et al., 2013). This species is a large, tall deciduous tree, and it can grow up to $40 \mathrm{~m}$ high (Vipunngeun \& Palanuvej, 2009). B. glabra is an arboreal ornamental plant, measuring 4 $6 \mathrm{~m}$, and it is a native species to northeast and southeast Brazil, occurring in tropical and subtropical regions of America and Europe (Pospísil \& Hrachová, 1987; Lorenzi, 1992).

Both species are potential oil production species because their seeds have high oil content of a good quality. Oil content in dry mass can reaches $20 \%$ in Bombacopsis glabra (Pasq.) and 50-60\% in Steculia foetida (Bindhu et al., 2012), being higher than found in conventional species such as soy (18\%) (Beltrão 2005). The experiment was conducted in a greenhouse ( $8^{\circ} 08^{\prime} 58^{\prime}$ 'S; $\left.34^{\circ} 56{ }^{\prime} 55^{\prime \prime} \mathrm{W}\right)$ in Northeast Brazil. The seeds, collected in the same region of the study, were previously sterilized in a $1 \%$ sodium hypochlorite solution for $5 \mathrm{~min}$, and then washed with distilled water. The sterilized seeds were subsequently planted in 10 $\mathrm{kg}$ perforated plastic pots with washed sand and placed in the greenhouse. The plants were kept under ideal hydration, calculated by the pot capacity, for 140 days after emergency when saline treatments begun.

The control treatment received $300 \mathrm{~mL}$ of deionized water daily, and the salinity treatments received 300 $\mathrm{mL}$ of sodium chloride solution $(100 \mathrm{mM} \mathrm{NaCl})$ daily for 23 days (maximum stress; gas exchange close to zero). Ten replicates per treatment were used for measurements. Five plants were used for biomass and nutrient concentrations analysis, and five for other 
parameter estimations. Every seventh day, $300 \mathrm{~mL}$ of $100 \%$ nutrient solution (Hoagland \& Arnon, 1950) was applied to both treatments.

Under maximum stress, leaf water potential (LWP) was measured with a Scholander pressure chamber (Soil moisture Equipment Corp., Santa Barbara, CA, USA) on a branch with fully expanded but not senescent leaves (Scholander et al., 1965). Measurements were performed at 6 AM. Soil samples were collected, weighed $(10 \mathrm{~g}$ of sand), and homogenized in $25 \mathrm{~mL}$ of deionized water. This solution was stirred three times for $2 \mathrm{~min}$, with a 2-min interval between each stirring, totalizing 10 $\mathrm{min}$. The solution was kept at rest for $40 \mathrm{~min}$. Then, the supernatant was collected for electrical conductivity and $\mathrm{pH}$ measurements using a conductivity meter (CD-4306, Lutron Electronic Enterprise Co., Taipei, Taiwan, China) and a pH-coupled meter (Bel Engineering W3B, Monza, Italy). The soil moisture (SM) was measured every day, obtained at a depth of $30 \mathrm{~cm}$ using a HFM 2030 sensor (v/v) (Falker, Porto Alegre, BR) (Table 1).

Gas exchange measurements were performed in alternate days starting from the third day of stress from $9 \mathrm{AM}$ to $11 \mathrm{AM}$ using a portable infrared $\mathrm{CO}_{2}$ gas analyzer (IRGA, LI-COR, LI- 6400XT, Lincoln, NE, US). The photosynthetic photon flux density (PPFD) used to measure gas exchange was fixed in IRGA at $2,000 \mu \mathrm{mol} \mathrm{m} \mathrm{m}^{-2} \mathrm{~s}^{-1}$, according to the incident radiation at the time of measurement. Stomatal conductance $\left(g_{\mathrm{s}}\right)$, net photosynthetic rate $(A)$ and transpiration rate $(E)$ were measured on a mature, but not senescent leaf. During gas exchange measurements, vapor pressure deficit (VPD) was calculated using the formula $e_{\mathrm{s}} e_{\mathrm{a}}$, where $e_{\mathrm{s}}$ is saturated vapor pressure, and $e_{\mathrm{a}}$ is environmental pressure deficit (Campbell \& Norman, 1998), obtained using temperature and relative humidity and measured with a digital thermohygrometer (Termo-Higro SH 122, J Prolab. São José dos Pinhais, BR).

To evaluate variable chlorophyll fluorescence, leaves were adapted to dark for $30 \mathrm{~min}$, and after a saturation light pulse at $\sim 7,800 \mu \mathrm{mol} \mathrm{m}^{-2} \mathrm{~s}^{-1}$, the minimal fluorescence from dark-adapted $\left(F_{\mathrm{o}}\right)$ and maximal fluorescence from dark-adapted $\left(F_{\mathrm{m}}\right)$ leaves were calculated. Fluorescence emission from light-adapted $\left(F^{\prime}\right)$ and maximal fluorescence from light-adapted $\left(F_{\mathrm{m}}{ }^{\prime}\right)$ leaves were determined for light-adapted leaves undergoing a stable photosynthesis. The chlorophyll fluorescence was measured using a portable infrared $\mathrm{CO}_{2}$ gas analyzer (IRGA, LI-COR, LI- 6400XT, Lincoln, NE, US). These data were used to calculate the following fluorescence parameters: maximum quantum efficiency of PSII photochemistry $\left(F_{\mathrm{v}} / F_{\mathrm{m}}\right)$, PSII operating efficiency $\left(F_{\mathrm{q}}, F_{\mathrm{m}}\right)$, photochemical quenching $(q P)$, electron transport rate $(E T R)$ and non-photochemical quenching (NPQ) (Baker, 2008).

About $3 \mathrm{~g}$ of fresh leaf samples were collected at day 23 (maximum stress) at 3 PM, considered the period of the day with the highest photoassimilate accumulation (Santos \& Pimentel, 2009). The samples were immediately frozen in liquid nitrogen and stored at $-20^{\circ} \mathrm{C}$. They were used to determine total soluble sugars (SS), free amino acids (FAA), total soluble proteins (TSP), chlorophyll a (Chla), chlorophyll b (Chlb) and carotenoids (Car). Biochemical measurements were performed using a double beam spectrophotometer (Genesis 10S UV-Vis, USA).

For extraction and measurement of SS and FAA, 50 mg of leaf fresh tissue from both species were used to prepare ethanol extract. SS were measured according to Dubois et al. (1956) using $\mathrm{D}(+)$ - glucose as a standard, and read at an absorbance of $490 \mathrm{~nm}$. FAA analyses were performed according to Moore \& Stein (1948) using a $1 \mathrm{mM}$ solution of glycine, glutamic acid, phenylalanine and arginine as a standard, and read at an absorbance of $570 \mathrm{~nm}$. To determine TSP concentration, $30 \mathrm{mg}$ (S. foetida) and $100 \mathrm{mg}$ (B. glabra) of leaf tissue were homogenized in a medium containing $10 \%(\mathrm{v} / \mathrm{v})$ glycerol, $0.1 \%(\mathrm{w} / \mathrm{v})$ bovine serum albumin, $0.1 \%(\mathrm{v} / \mathrm{v})$ Triton X-100, $50 \mathrm{mM}$ HEPES/KOH $(\mathrm{pH}$ 7.4), $5 \mathrm{mM} \mathrm{MgCl}_{2}, 1 \mathrm{Mm}$ EDTA, $1 \mathrm{mM}$ EGTA and $5 \mathrm{mM}$ dithiothreitol. Leaf protein concentration was estimated according to Bradford (1976) using bovine serum albumin as a standard, and read at an absorbance of $595 \mathrm{~nm}$. Leaf concentration of Chl $a$, Chl $b$ and Car were analyzed by homogenizing $30 \mathrm{mg}$ (S. foetida) and $50 \mathrm{mg}$ (B. glabra) of leaf tissue into $2 \mathrm{~mL}$ of acetone $(80 \%)$ with $\mathrm{CaCO}_{3}$ to prevent chlorophyllase activity. The samples were filtered and read at absorbances of 470.0, 646.8 and $663.2 \mathrm{~nm}$, for Chl $a, \mathrm{Chl} b$ and Car concentration, respectively. Additionally, a nonspecific absorbance at $710 \mathrm{~nm}$ was recorded for correction of color, turbidity and contaminating compounds in samples for Chl $a, \mathrm{Chl} b$ and Car measurements, because those pigments do not absorb in this wavelength. Final pigment concentrations were calculated as described by Lichtenthaler \& Buschmann (2001).

For quantification of nitrogen, phosphorus, potassium, calcium and sodium, approximately $250 \mathrm{mg}$ of fresh leaves were collected, dried in a forced-air oven at $60^{\circ} \mathrm{C}$ 
for $72 \mathrm{~h}$ and ground in an industrial blender. Then they were digested in an acid solution $\left(\mathrm{H}_{2} \mathrm{SO}_{4}\right)$ in a digester block at $350{ }^{\circ} \mathrm{C}$, to obtain plant extracts (Thomas et al., 1967). Total $\mathrm{N}$ concentration was determined from an extract titration with $\mathrm{HCl}$ after addition of boric acid and a colored indicator (Thomas et al., 1967). Phosphorus concentration was determined spectrophotometrically (Spectrophotometer 600S, FEMTO, São Paulo, BR), according to Murphy \& Riley (1962), using a concentration curve for phosphorus. $\mathrm{K}^{+}, \mathrm{Ca}^{2+}$ and $\mathrm{Na}^{+}$ concentration were determined by flame photometry (DM-62, Digimed, São Paulo, BR) using a solution of 5 ppm K$~_{+}, \mathrm{Ca}^{2+}$ and $\mathrm{Na}^{+}$, respectively, as standards (Silva, 2009).

To determine chloride $\left(\mathrm{Cl}^{-}\right), 500 \mathrm{mg}$ of dry leaves were used. The extracts were obtained by Mohr's method (water bath at $90{ }^{\circ} \mathrm{C}$ for $20 \mathrm{~min}$ ), and concentration was determined from an extract titration with silver nitrate $\left(\mathrm{AgNO}_{3}\right)$ after addition of potassium chromate $\left(\mathrm{K}_{2} \mathrm{CrO}_{4}\right)$ and a colored indicator (Lacroix et al., 1970).

When maximum stress was attained ( $23^{\text {rd }}$ day), all leaves, stem and roots were collected, separated into shoot (leaves and stems) and root materials, and dried in a forced-air oven at $60{ }^{\circ} \mathrm{C}$ for $72 \mathrm{~h}$. After, plant parts were weighed to obtain dry mass $(\mathrm{g})$. Shoot/root ratio was also calculated.

Experimental design was completely randomized. Data of gas exchange, chlorophyll $a$ fluorescence, leaf biochemical and nutrients were submitted to $t$ test with a significance level of 5\%, comparing saline conditions [non-saline (control) and saline]. In all analyses all the prerequisites (normality and homogeneity) were respected. Data were analyzed using the software Statistica 8.0 (StatSoft. Inc., Tulsa, OK 74104, USA).

\section{Results}

Under maximum stress conditions (day 23), leaf water potential (LWP) in Sterculia foetida control plants was $-0.57 \mathrm{MPa}$, decreasing $72 \%$ in saline treatment (Table 1 ). In Bombacopsis glabra control plants, LWP was -0.29 $\mathrm{MPa}$, decreasing $155 \%$ in saline treatment. Electrical conductivity was 1.8 and $1.6 \mathrm{mS} . \mathrm{cm}^{-1}$ in soil referent to control plants of $S$. foetida and B. glabra, respectively, with an increase of $178 \%$ and $419 \%$ in saline treatments. Soil $\mathrm{pH}$ referent to control plants was 6.05 and 7.45 for $S$. foetida and B. glabra, with similar values in saline treatment for each species.
Table 1. Means and standard error $( \pm$ S.E $)$ of leaf water potential (LWP) of Sterculia foetida and Bombacopsis glabra plants submitted to saline and hydrated conditions in a greenhouse, followed by soil $\mathrm{pH}$ and electrical conductivity.

\begin{tabular}{ccccc}
\hline \multirow{2}{*}{ Variables } & \multicolumn{4}{c}{ Species } \\
& \multicolumn{2}{c}{ Soetida } & \multicolumn{2}{c}{ B. glabra } \\
\cline { 2 - 5 } & Control & Salt & Control & Salt \\
\hline LWP $(\mathrm{MPa})$ & $-0.57 \pm 0.04^{\mathrm{a}}$ & $-0.98 \pm 0.04^{\mathrm{b}}$ & $-0.29 \pm 0.03^{\mathrm{a}}$ & $-0.74 \pm 0.07^{\mathrm{b}}$ \\
$\mathrm{pH}$ & $6.05 \pm 0.07$ & $6.07 \pm 0.21$ & $7.45 \pm 0.02$ & $7.59 \pm 0.83$ \\
$\begin{array}{c}\text { Conductivity } \\
\left.(\mathrm{mS} \mathrm{cm})^{-1}\right)\end{array}$ & $1.8 \pm 0.01$ & $5.0 \pm 0.09$ & $1.6 \pm 0.01$ & $8.3 \pm 0.08$ \\
\hline
\end{tabular}

Different letters in lines mean the significant difference obtained by $\mathrm{t}$ test $\mathrm{p}$ $<0.05)$ for each species $(n=5)$.

Soil moisture (SM) differed between treatments after the sixth day of saline irrigation, with the soil under saline treatment resulting in values significantly higher than the control treatment in both species. Under maximum stress, $S$. foetida and B. glabra control plants showed values of $12 \%$, with increases of $75 \%$ and $77 \%$ in saline treatments, respectively (Figure 1).

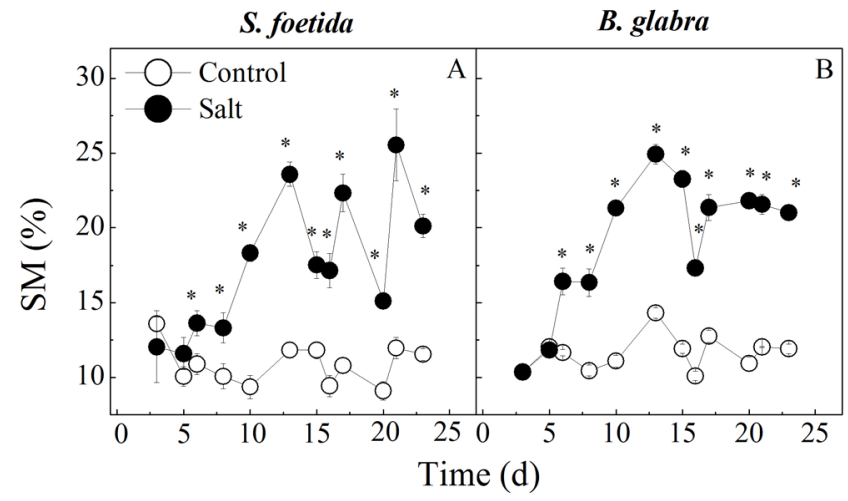

Figure 1. Mean and standard error $( \pm S$ S.E) values of soil moisture (SM) of saline and hydrated treatments applied on plants of (A) Sterculia foetida and (B) Bombacopsis glabra under greenhouse conditions. Means with asterisk were significantly different from their respective pair by $\mathrm{t}$ test $(\mathrm{p}$ $<0.05)(\mathrm{n}=5)$.

A reduction in gas exchange was observed from the fifth day of saline irrigation for both species, except for net photosynthetic rate $(A)$ in $B$. glabra, which showed a reduction from the sixth day, compared to control (Figure 2). Under maximum stress, S. foetida plants grown under salt treatment showed a decrease of $97 \%$ in stomatal conductance $\left(g_{\mathrm{s}}\right)$ and $95 \%$ in $A$ and transpiration rate $(E)$ compared to control (Figures $2 \mathrm{a}, 2 \mathrm{c}$ and $2 \mathrm{e}$ ). In the same period, $B$. glabra plants under treatment with elevated soil salt showed decreases of $83 \%, 166 \%$ and 
$78 \%$ in $g_{\mathrm{s}}, A$ and $E$, respectively, compared to control (Figures 2b, 2d and 2f). Vapor pressure deficit (VPD) varied between $0.83 \mathrm{kPa}$ and $2.9 \mathrm{kPa}$ throughout the experiment period (Figure $2 \mathrm{~g}$ ).

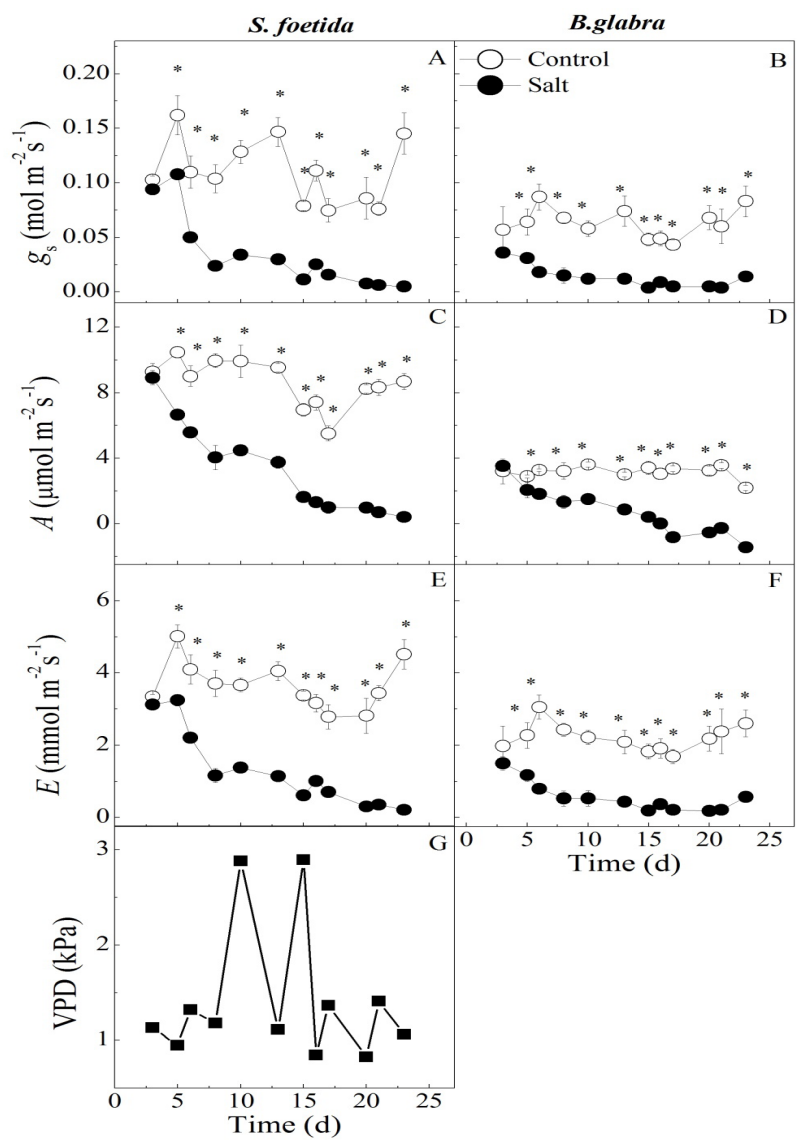

Figure 2. Mean and standard error $( \pm$ S.E) values of leaf gas exchange in Sterculia foetida and Bombacopsis glabra plants submitted to saline and hydrated (control) treatments in a greenhouse. (A, B) $g_{\mathrm{s}}$ - stomatal conductance; (C, D) $A$ - net photosynthetic rate; (E, F) $E$ - transpiration rate; (G) VPD vapor pressure deficit. Means with asterisk were significantly different from their respective pair by $t$ test $(p<0.05)(n=5)$.

In chlorophyll fluorescence parameters, maximum quantum efficiency of PSII photochemistry $\left(F_{\mathrm{v}} / F_{\mathrm{m}}\right)$ was above 0.7 for control and saline treatment in both species throughout the experiment. For $S$. foetida, the other parameters, except non-photochemical quenching $(N P Q)$, decrease from the sixth day of experiment in the saline treatment. For $B$. glabra, PSII operating efficiency $\left(F_{\mathrm{q}}{ }^{\prime} / F_{\mathrm{m}}{ }^{\prime}\right)$ decreased in the same day, but photochemical quenching $(q P)$ and electron transport rate $(E T R)$ decreased from the eighth day of experiment. The $N P Q$ showed an increase in $S$. foetida in three moments in saline treatment plants (sixth, $20^{\text {th }}$ and maximum stress day), while in B. glabra an increase was noted from the tenth day of experiment. In maximum stress, $S$. foetida saline treatment plants showed a reduction of $50 \%, 28 \%$ and $51 \%$ in $F_{\mathrm{q}}{ }^{\prime} / F_{\mathrm{m}},{ }^{\prime}, q P$ and $E T R$, respectively. $N P Q$ was $143 \%$ higher compared to control (Figures 3a, 3c, 3e and $3 \mathrm{~g}$ ). In $B$. glabra, saline treatment plants showed decreases in $F_{\mathrm{q}}{ }^{\prime} / F_{\mathrm{m}}, q P$ and $E T R$ of $51 \%, 54 \%$ and $48 \%$, respectively. $N P Q$ showed an increase of $51 \%$ compared to control (Figures 3b, 3d, 3f and 3h).

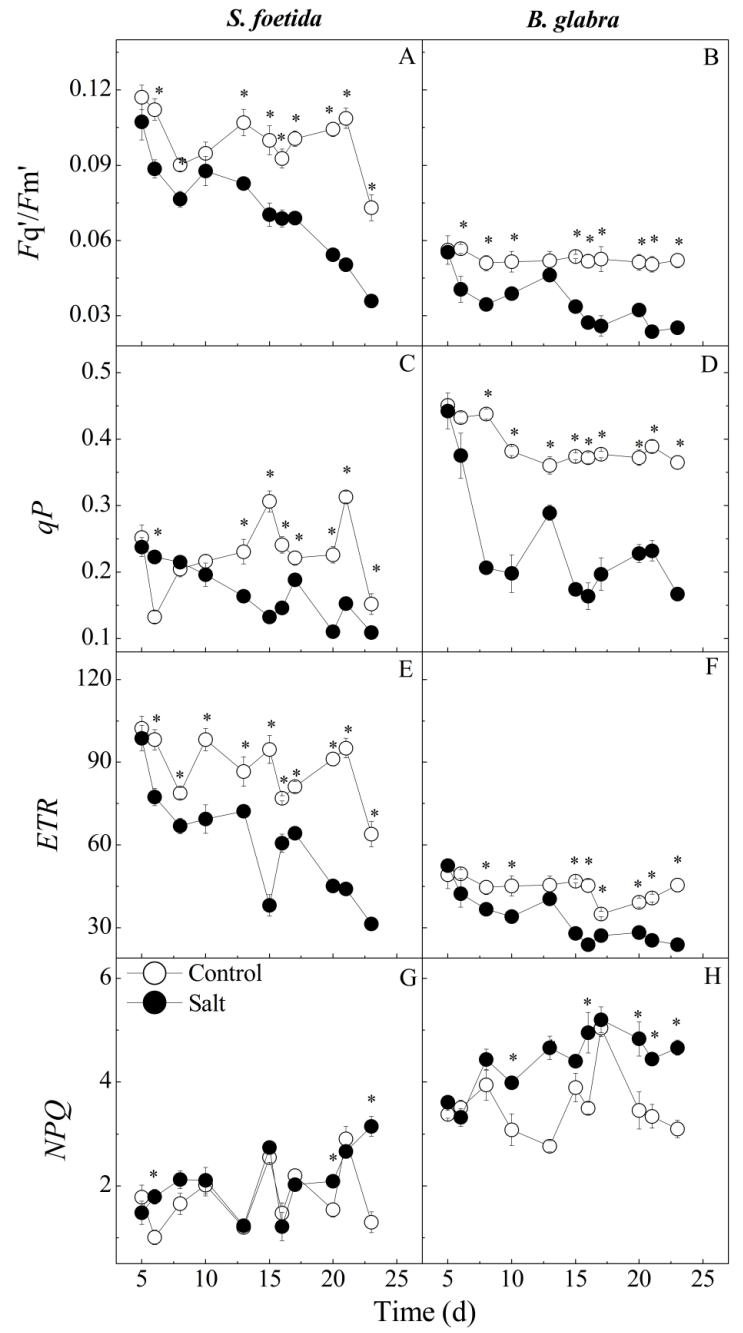

Figure 3. Mean and standard error $( \pm$ S.E $)$ values for leaf chlorophyll $a$ fluorescence parameters of Sterculia foetida and Bombacopsis glabra plants submitted to saline and hydrated (control) treatment in a greenhouse. (A, B) $F_{\mathrm{q}}$ '/ $F_{\mathrm{m}}$ ' - PSII operating efficiency; $(\mathrm{C}, \mathrm{D}) q P$ - photochemical quenching; (E, F) ETR - electron transport rate; $(\mathrm{G}, \mathrm{H}) ; N P Q$ - non-photochemical quenching. Means with asterisk were significantly different from their respective pair compared by t test $(\mathrm{p}<0.05)(\mathrm{n}=5)$. 
S. foetida plants did not differ regarding concentration of photosynthetic pigments among treatments (Table 2). B. glabra saline treatment showed an increase in the concentration of chlorophyll a (Chla) and carotenoids (Car) of $61 \%$ and $43 \%$, respectively, compared to the control. chlorophyll b (Chlb) did not differ among treatments (Table 2). S. foetida plants under salt conditions showed a reduction of $34 \%$ in total soluble sugars (SS), an increase of $33 \%$ in free amino acids (FAA), and $27 \%$ reduction in total soluble proteins (TSP) compared to control treatment. B. glabra under salt stress showed a reduction of $15 \%$ and $29 \%$ in SS and TSP, respectively, compared to control, while FAA did not differ among treatments, with values around 32 mmol kg ${ }^{-1}$ DW (Table 2).

Table 2. Mean and standard error $( \pm$ S.E) values for organic solutes (soluble sugars - SS; free amino acids - FAA; total soluble proteins - TSP) and photosynthetic pigments (chlorophyll a - Chla; chlorophyll b Chlb; carotenoids - Car) of Sterculia foetida and Bombacopsis glabra plants submitted to saline and hydrated conditions in a greenhouse in the maximum stress day.

\begin{tabular}{ccccc}
\hline \multirow{2}{*}{ Variables } & \multicolumn{3}{c}{ Species } \\
\cline { 2 - 5 } & \multicolumn{2}{c}{ S. foetida } & Control & B. glabra \\
\cline { 2 - 5 } & Control & $426.6 \pm 20.7^{\mathrm{b}}$ & $603.8 \pm 18.2^{\mathrm{a}}$ & $512.9 \pm 11.7^{\mathrm{b}}$ \\
\hline $\mathrm{SS}\left(\mathrm{mmol} \mathrm{kg}^{-1} \mathrm{DW}\right)$ & $647.7 \pm 14.7^{\mathrm{a}}$ & $26.4 \pm 1.2^{\mathrm{a}}$ & $33.8 \pm 3.6^{\mathrm{ns}}$ & $31.9 \pm 5.2$ \\
FAA $\left(\mathrm{mmol} \mathrm{kg}^{-1} \mathrm{DW}\right)$ & $19.8 \pm 1.1^{\mathrm{b}}$ & $112.6 \pm 8.6^{\mathrm{b}}$ & $51.5 \pm 9.2^{\mathrm{a}}$ & $36.6 \pm 3.0^{\mathrm{b}}$ \\
TSP $\left(\mathrm{g} \mathrm{kg}^{-1} \mathrm{DW}\right)$ & $154.6 \pm 15.9^{\mathrm{a}}$ & $4.7 \pm 0.3$ & $1.0 \pm 0.1^{\mathrm{b}}$ & $1.7 \pm 0.2^{\mathrm{a}}$ \\
Chl $a\left(\mathrm{~g} \mathrm{~kg}^{-1} \mathrm{DW}\right)$ & $4.5 \pm 0.1^{\mathrm{ns}}$ & $1.5 \pm 0.1$ & $0.6 \pm 0.1^{\mathrm{ns}}$ & $0.7 \pm 0.1$ \\
Chl $b\left(\mathrm{~g} \mathrm{~kg}^{-1} \mathrm{DW}\right)$ & $1.5 \pm 0.1^{\mathrm{ns}}$ & $1.3 \pm 0.1$ & $0.5 \pm 0.1^{\mathrm{b}}$ & $0.7 \pm 0.1^{\mathrm{a}}$ \\
Car$\left(\mathrm{g} \mathrm{kg}^{-1} \mathrm{DW}\right)$ & $1.3 \pm 0.0^{\mathrm{ns}}$ &
\end{tabular}

Different letters in lines mean significant difference obtained by $\mathrm{t}$ test $(\mathrm{p}<0.05)$ for each species $(\mathrm{n}=5)$.

Under salt conditions, $S$. foetida showed high $\mathrm{N}, \mathrm{K}^{+}$ and $\mathrm{Cl}^{-}$leaf concentrations of $11 \%, 32 \%$ and $140 \%$, respectively, while $\mathrm{Ca}^{2+}$ concentration was $16 \%$ lower than in control treatment (Figure 4a). Furthermore, leaf concentration of $\mathrm{P}$ and $\mathrm{Na}^{+}$and $\mathrm{Na}^{+} / \mathrm{K}^{+}$ratio did not differ among treatments. In B. glabra plants under stress, $\mathrm{K}^{+}$ concentration was $29 \%$ lower, while $\mathrm{Na}^{+}, \mathrm{Cl}^{-}$and $\mathrm{Na}^{+} / \mathrm{K}^{+}$ ratio were $224 \%, 166 \%$ and $364 \%$ higher, respectively, when compared to control treatment (Figure $4 \mathrm{~b}$ ). N, P and $\mathrm{Ca}^{2+}$ did not differ among treatments.

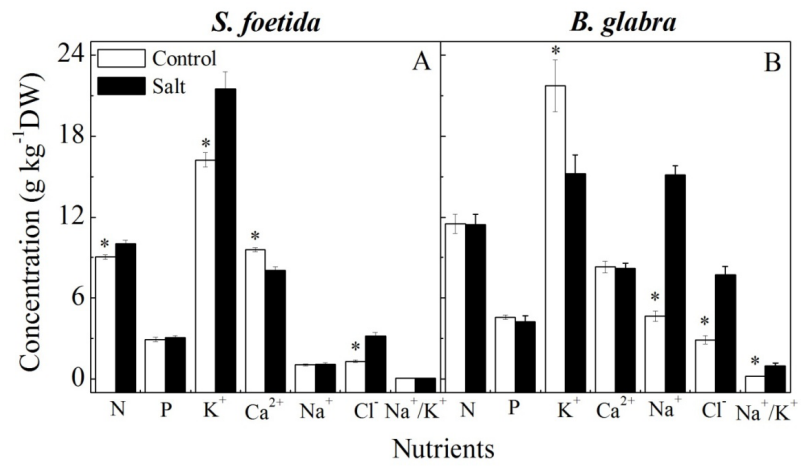

Figure 4. Mean and standard error $( \pm \mathrm{S}$.E) values for leaf nutrient concentration of $\mathrm{N} ; \mathrm{P} ; \mathrm{K}^{+} ; \mathrm{Ca}^{2+} ; \mathrm{Na}^{+} ; \mathrm{Cl}$; and $\mathrm{Na}^{+} / \mathrm{K}^{+}$ in (A) Sterculia foetida and (B) Bombacopsis glabra plants submitted to saline and hydrated (control) treatment in a greenhouse in the maximum stress day. Bars with asterisk were significantly different from their respective pair compared by t test $(\mathrm{p}<0.05)(\mathrm{n}=5)$.

\section{Discussion}

The decrease in $\mathrm{CO}_{2}$ assimilation and transpiration observed in plants of the saline treatment is directly related to decrease in stomatal conductance $\left(g_{\mathrm{s}}\right)$ for both species (Figure. 2) due to low leaf water potential (Table 1).

High salt concentrations in the soil reduce its osmotic potential, lead to a hyperosmotic stress and affect water absorption by roots (Tester \& Davenport, 2003). Thus, it decreased leaf water potential (LWP) in stressed plants (Table 1), probably causing stomatal closure and depletion in photosynthetic capacity, probably due to lower osmotic potential in the soil in saline treatment (Munns \& Tester, 2008; Gupta \& Huang, 2014). Richards et al. (2008) argued that a common response to salinity is stomatal closure, because it reduces water loss by transpiration and an excessive absorption of ions, leading to a decrease in $\mathrm{CO}_{2}$ capturing.

Photosynthesis and cell growth are among the primary processes affected by salinity (Munns et al., 2006) due to the decrease in $\mathrm{CO}_{2}$ availability caused by diffusion limitations through the stomata and the mesophyll (Flexas et al., 2007). This reduction in stomatal conductance and $\mathrm{CO}_{2}$ assimilation (Figure 2) was also found for Ricinus communis L. and Jatropha curcas (Rodrigues et al., 2014). Together with the decrease 
in net photosynthetic rate $(A)$, there was decrease in chlorophyll a $(\mathrm{Chl} a)$ fluorescence parameters, except for non-photochemical quenching $(N P Q)$ for the two species in the saline treatment. This result indicates that plants are increasing the action of alternative electron drainages, such as energy dissipation in the form of heat, to avoid damage to photosynthetic apparatus due to reactive oxygen species (ROS) formation (Heber, 2002; Ribeiro et al., 2004; Deilen et al., 2014; Hossain \& Dietz, 2016). Furthermore, it is reported that plants from semiarid environments, where light is not a limiting factor, increase their photorespiration rates (Flexas et al., 1999). No chronic damage to photosynthetic apparatus was observed in the plants, evidenced by the high values of maximum quantum efficiency of PSII photochemistry $\left(F_{\mathrm{v}} / F_{\mathrm{m}}\right)$. Similar results were found by Souza et al. (2010) studying two tree species from semiarid under water stress. Electron transport rate $(E T R)$ and photochemical quenching $(q P)$ values decreased and were accompanied by an increase in $N P Q$. Li et al. (2010) had similar results with Ricinus communis L. treated with $100 \mathrm{mM}$ saline solution.

B. glabra plants under stress showed an increased Chla and carotenoids (Car) leaf concentration. The increase in Chla helps to protect photosynthetic machinery by maintaining electron flow to Calvin-Benson cycle. It is crucial to prevent cell damage due to photo-oxidative stress (Heber et al., 2001). Thus, protection of antenna complex could be achieved by zeaxanthin cycle (Asada, 1999; Heber et al., 2001). A high leaf concentration of Chl $a$ and Car may mean that photosynthetic apparatus acclimated to the stress condition (Tezara et al. 2011) as indicated by higher values of $F_{\mathrm{v}} / F_{\mathrm{m}}$. Car may have acted in photoprotection and/or energy dissipation, in an attempt to alleviate the salt negative effects in plants, together to elevated NPQ values.

Water deficit in plant cells by salt stress may affect the biochemistry of chloroplasts, contributing to decrease photosynthetic performance (Farquhar \& Sharkey, 1982) and reducing sugar concentrations in many plants (Esteves \& Suzuki, 2008). The decreased $g_{\mathrm{s}}$ in stressed plants of both species (Figure 2) was accompanied by a decrease in their SS concentration (Table 2). This reduction in $g_{\mathrm{s}}$ directly affects the $\mathrm{CO}_{2}$ concentration in the mesophyll and impairs the formation of trioses-P in chloroplasts, which are used in the synthesis of soluble sugars (Ludewig \& Ingo-Flügge, 2013). In addition to total soluble sugars (SS), total soluble proteins (TSP) also decreased (Table 2), which may have been due to synthesis depletion caused by the loss of cell turgor (Hsiao, 1973).

In $S$. foetida plants under stress, free amino acids (FAA) and $\mathrm{N}$ leaf concentration increased (Table 2, Figure 4). In salt-acclimated plants, it was shown that metabolites linked to amino acids and nitrogen increased in the cell. FAA play a role in osmotic adjustment, membrane and protein protection, and/or scavenging of ROS (Chaves et al., 2009).

Another mineral element that plays a key role in plant metabolism is $\mathrm{K}^{+}$, such as in stomatal closure controlling turgor pressure of guard cells (Wang et al., 2012). Both species presented elevated leaf concentrations of $\mathrm{K}^{+}$ (Figure 4). However, in $S$. foetida, $\mathrm{K}^{+}$concentration was higher in stressed than in control plants, unlike that observed for B. glabra. Despite both species presented a decrease on $g_{\mathrm{s}}$ in saline treatment plants, the decrease in $S$. foetida was markedly higher than in B. glabra. Some authors discussed that plants with high $\mathrm{K}^{+}$levels have a greater stomatal opening regarding water deficit (Benlloch-González et al., 2012), which was not observed in S. foetida. $\mathrm{K}^{+}$may have acted in turgor cell recovery in osmotic stress situations, promoting tolerance to physiological drought caused by salinity (Evelin et al., 2009). On the other hand, the decrease observed in leaf $\mathrm{Ca}^{2+}$ concentration in $S$. foetida stressed plants suggests that there were changes in absorption and metabolism of this element, where $\mathrm{Na}^{+}$may have replaced $\mathrm{Ca}^{2+}$ in cell membranes, affecting its permeability (Esteves \& Suzuki, 2008; Willadino \& Câmara, 2010).

Unlike $S$. foetida, stressed B. glabra plants showed the same levels of $\mathrm{Ca}^{2+}$ compared to control. $\mathrm{Ca}^{2+}$ concentration in cytosol is usually very low, which is a precondition for $\mathrm{Ca}^{2+}$ acting as a signalling compound in plant cells (Clarkson \& Hanson, 1980; Knight \& Knight, 2001). Currently, $\mathrm{Ca}^{2+}$ is a second indicator of stress responses and its role in SOS pathway are among the best-studied salt signalling mechanisms in plants (Zhu, 2003). Stressed plants of B. glabra had a higher $\mathrm{Na}^{+} / \mathrm{K}^{+}$ratio. Metabolic changes caused by high levels of $\mathrm{Na}^{+}$in cells mainly result from $\mathrm{K}^{+}$competition for active sites of enzymes (Blumwald et al., 2000) and ribosomes (Tester \& Davenport, 2003). Prevention of $\mathrm{Na}^{+}$absorption by roots, sequestration into vacuole and transport and/or allocation to leaves are strategies by which plants cope with and keep healthy in high-salt environments (Porcel et al., 2012). 
$\mathrm{Cl}^{-}$is translocated to leaves in both species, but $\mathrm{Na}^{+}$ is the most toxic ion (Tester \& Davenport, 2003). It did not show high concentrations in leaves of $S$. foetida, unlike $B$. glabra, indicating that $S$. foetida could have a high efficiency in exclusion and/or allocation of $\mathrm{Na}^{+}$in roots or stems. Freire \& Miranda (2012) found similar results of $B$. glabra for Moringa oleifera.

From these results, it was observed that $S$. foetida and B. glabra present physiological changes that allow these species to adjust to a saline environment, typical of semiarid areas in Brazilian northeast region. Stomatal closure in response to saline treatment was common to both species. This decrease in stomatal conductance resulted in decreases of water loss through transpiration, in assimilation rates and, therefore, in SS and TSP concentrations. However, species presented different strategies regarding organic solutes, pigments and nutrients in response to salt stress. S. foetida increased FAA and $\mathrm{N}$ of leaves without accumulating $\mathrm{Na}^{+}$, thus indicating a possible cellular protection mechanism. On the other hand, B. glabra had higher concentrations of $\mathrm{Chl} a$ and Car, indicating an investment in photoprotection against damage probably caused by the accumulation of $\mathrm{Na}^{+}$and $\mathrm{Cl}^{-}$in leaves, with a higher $\mathrm{Na}^{+} / \mathrm{K}^{+}$ratio.

\section{Conclusions}

In this scenario, we conclude that Sterculia foetida and Bombacopsis glabra have some tolerance to salt stress, because both supported 23 days of intense saline irrigation. However, their strategies are different. $S$. foetida plants under salinity no had accumulation of $\mathrm{Na}^{+}$in leaves compared to control, indicating that these plants could have a higher efficiency in exclusion and/or allocation of $\mathrm{Na}^{+}$in roots or stems, avoiding an osmotic stress in leaves. Furthermore, these plants accumulated $\mathrm{K}^{+}$, indicating an investment in ionic balance. $B$. glabra salt plants had a greater accumulation of $\mathrm{Na}^{+}$ in leaves, with an increase in photosynthetic pigments, mainly carotenoids. This behaviour indicated that $B$. glabra under salinity invested in photoprotection. Results obtained in this study lead us to think of a better performance of these species in field condition, because soil salinization does not happen so quickly and intensely. Thus, these species may represent an alternative in Brazilian northeast region where water deficit and salt stress are challenging for annual crops.

\section{Acknowledgements}

The authors would like to thank to the funding support from CNPq (Proc. 551300/2010-8) and FACEPE (Proc. APQ - FACEPE 0929-5.01/10). B. M. Lustosa is grateful to FACEPE for the research scholarship and, M.G. Santos thanks CNPq for providing a fellowship.

\section{References}

Aguiar Neto, A. O. et al. Characteristics chemical and soil salinization in the Irrigated District of California, SE, Brazil. Ciência Rural, v. 37, p. 1640-1645, 2007. DOI: 10.1590/S0103-84782007000600021.

Asada, K. The water-water cycle in chloroplasts: scavenging of active oxygens and dissipation of excess photons. Annual Review of Plant Physiology and Plant Molecular Biology, v. 50, p. 601-639, 1999. DOI: 10.1146/annurev.arplant.50.1.601.

Beltrão, N. E. de M. Agronegócio das oleaginosas no Brasil. Informe Agropecuário, v. 26, n. 229, p. 18, 2005

Baker, N. R. Chlorophyll fluorescence: a probe of photosynthesis in vivo. Annual Review of Plant, v. 59, p. 89-113, 2008. DOI: 10.1146/ annurev.arplant.59.032607.092759.

Benlloch-González, M. et al. $\mathrm{K}^{+}$starvation causes a differential effect on shoot and root $\mathrm{K}^{+}\left(\mathrm{Rb}^{+}\right)$uptake in sunflower plants. Scientia Horticulturae, v. 146, p. 153-158, 2012. DOI: 10.1016/j. scienta.2012.08.030.

Bindhu, C. et al. Preparation and evaluation of biodiesel from Sterculia foetida seed oil. Journal of the American Oil Chemists' Society, v. 89, p. 891-896, 2012. DOI: 10.1007/s11746-011-1969-7.

Blumwald, E. et al. Sodium transport and salt tolerance in plant cells. Current Opinion of Cell Biology, v. 12, p. 76-112, 2000. DOI: 10.1016/S0005-2736(00)00135-8.

Bradford, M. M. A rapid and sensitive method for the quantitation of microgram quantities of protein utilizing the principle of protein-dye binding. Analytical Biochemistry, v. 72, p. 248-254, 1976. DOI: 10.1016/0003-2697(76)90527-3

Campbell, G. S. \& Norman, J. M. An introduction to environmental biophysics. Nova York: Springer-Verlag, 1998. 286 p.

Chaves, M. H. et al. Chemical Characterization and Stability of the Bombacopsis glabra Nut Oil. Food and Public Health, v. 2, p. 104109, 2012. DOI: 10.5923/j.fph.20120204.04.

Chaves, M. M. et al. Photosynthesis under drought and salt stress: regulation mechanisms from whole plant to cell. Annals of Botany, v. 103, p. 551-560, 2009. DOI: 10.1093/aob/mcn 125 .

Clarkson, D. T. \& Hanson, J. B. The mineral nutrition of higher plants. Annual Review of Plant Physiology, v. 31, p. 239-298, 1980. DOI: 10.1146/annurev.pp.31.060180.001323.

Deilen, U. et al. Plant salt-tolerance mechanisms. Trends in Plant Science, v. 19, p. 371-379, 2014. DOI: 10.1016/j.tplants.2014.02.001.

Dubois, M. et al. Colorimetric method for determination of sugars and related substances. Analytical Chemistry, v. 28, p. 350-356, 1956. DOI: 10.1021/ac60111a017. 
Esteves, B. S. \& Suzuki, M. S. Efeito da salinidade sobre as plantas. Oecologia Brasilienses, v. 12, p. 662-679, 2008.

Evelin, H. et al. Arbuscular mycorrhizal fungi in alleviation of salt stress: a review. Annals of Botany, v. 104, p. 1263-1280, 2009. DOI: $10.1093 / \mathrm{aob} / \mathrm{mcp} 251$.

Farquhar, G. D. \& Sharkey, T. D. Stomatal conductance and photosynthesis. Annual Review of Plant Physiology, v. 33, p. 317-345, 1982. DOI: 10.1146/annurev.pp.33.060182.001533.

Feng, G. et al. Improved tolerance of maize plants to salt stress by arbuscular mycorrhiza is related to higher accumulation of soluble sugars in roots. Mycorrhiza, v. 12, p. 185-190, 2002. DOI: 10.1007/ s00572-002-0170-0.

Flexas, J. et al. Rapid variations of mesophyll conductance in response to changes in $\mathrm{CO}_{2}$ concentration around leaves. Plant, Cell and Environment, v. 30, p. 1284-1298, 2007. DOI: 10.1111/j.13653040.2007.01700.x.

Flexas, J. et al. Water stress induces different levels of photosynthesis and electron transport rate regulation in grapevines. Plant, Cell and Environment, v. 22, p. 39-48, 1999. DOI: 10.1046/j.13653040.1999.00371.x.

FAO. Advances in the assessment and monitoring of salinization and status of biosaline agriculture. World Soil Resources Reports, $\mathrm{n}$. 104. Rome, 2009. 73 p.

Freire, A. L. O. \& Miranda, J. R. P. Crescimento e acúmulo de cátions em plantas de moringa mantidas em solos salinos. Pesquisa Florestal Brasileira, v. 32, p. 45-51, 2012. DOI: 10.4336/2012.pfb.32.69.45.

Gupta, B. \& Huang, B. Mechanism of salinity tolerance in plants: Physiological, biochemical, and molecular characterization. International Journal of Genomics, v. 2014, p. 1-18, 2014. DOI: 10.1155/2014/701596.

Heber, U. Irrungen, Wirrungen? The Mehler reaction in relation to cyclic electron transport in C3 plants. Photosynthesis Research, v. 73, p. 223-231, 2002. DOI: 10.1023/A:102045941698

Heber, U. et al. Protection of the photosynthetic apparatus against damage by excessive illumination in homoiohydric leaves and poikilohydric mosses and lichens. Journal of Experimental Botany, v. 52, p. 1999-2006, 2001. DOI: 10.1093/jexbot/52.363.1999.

Hoagland, D. R. \& Arnon, D. I. The water culture method of growing plants without soil. Berkeley, CA: University of California, 1950. $32 \mathrm{p}$.

Hossain, M. S. \& Dietz, K. J. Tuning of redox regulatory mechanisms, reactive oxygen species and redox homeostasis under salinity stress. Frontiers in Plant Science, v. 7, p. 1-15, 2016. DOI: 10.3389/ fpls.2016.00548.

Hsiao, T. C. Plant response to water stress. Annual Review of Plant Physiology, v. 24, p. 519-570, 1973. DOI: 10.1146/annurev. pp.24.060173.002511.

Jahromi, F. et al. Influence of salinity on the in vitro development of Glomus intraradices and on the in vivo physiological and molecular responses of mycorrhizal lettuce plants. Microbial Ecology, v. 55, p. 45-53, 2008. DOI: 10.1007/s00248-007-9249-7.

Janz, D. \& Polle, A. Harnessing salt for woody biomass production. Tree Physiology, v. 32, p. 1-3, 2012. DOI: 10.1093/treephys/tpr127.
Knight, H. \& Knight, M. R. Abiotic stress signalling pathways: specificity and cross-talk. Trends in Plant Science, v. 6, p. 262-267, 2001. DOI: 10.1016/S1360-1385(01)01946-X.

Lacroix, R. L. et al. Potentiometric titration of chloride in plant tissue extracts using the chloride ion electrode. Communications in Soil Science and Plant Analysis, v. 1, p, 1-6, 1970. DOI: 10.1080/00103627009366233.

Lichtenthaler, H. K. \& Buschmann, C. Chlorophylls and carotenoids: measurement and characterization by UV-VIS spectroscopy. Current Protocols in Food Analytical Chemistry, F4.3.1, p. 1-8, 2001. DOI: 10.1002/0471142913.faf0403s01.

Li, G. et al. Leaf chlorophyll fluorescence, hyperspectral reflectance, pigments content, malondialdehyde and proline accumulation responses of castor bean (Ricinus communis L.) seedlings to salt stress levels. Industrial Crops and Products, v. 31, p. 13-19, 2010. DOI: 10.1016/j.indcrop.2009.07.015.

Lorenzi, H. (Ed.). Árvores brasileiras: manual de identificação e cultivo de plantas arbóreas nativas do Brasil. Nova Odessa: Plantarum, 1992. $384 \mathrm{p}$.

Ludewig, F. \& Ingo-Flügge, U. Role of metabolite transporters in source-sink carbon allocation. Frontiers in Plant Science, v. 4, p. 231, 2013. DOI: 10.3389/fpls.2013.00231.

Mathur, A. \& Vyas, D. K. Socio-ecological issues-eco-economic and sustainability status. Journal of Ecology and Environmental Sciences, v. 4, p. 87-90, 2013. DOI: 10.9735/0976-9900.4.1.87-90.

Moore, S. \& Stein, W. H. Photometric ninhydrin method for use in chromatography of amino acids. The Journal of Biological Chemistry, v. 176, p. 367-388, 1948.

Munns, R. et al. Approaches to increasing the salt tolerance of wheat and other cereals. Journal of Experimental Botany, v. 57, p. 1025-1043, 2006. DOI: 10.1093/jxb/erj100.

Munns, R. \& Tester, M. Mechanisms of Salinity Tolerance. Annual Review of Plant Biology, v. 59, p. 651-81, 2008. DOI: 10.1146/ annurev.arplant.59.032607.092911.

Murphy, J. \& Riley, J. P. A. A modified simple solution method for the determination of phosphate in natural waters. Analytica Chimica Acta, v. 27, p. 31-36, 1962. DOI: 10.1016/S0003-2670(00)88444-5.

Pachauri, R. K. \& Meyer, L. (Ed.). Climate Change 2014: synthesis report. Geneva, Switzerland: Intergovernmental Panel on Climate Change, 2014. $151 \mathrm{p}$.

Polle, A. \& Chen, S. On the salty side of life: molecular, physiological and anatomical adaptation and acclimation of trees to extreme habitats. Plant, Cell and Environment, v. 38, p. 1794-1816, 2015. DOI: $10.1111 /$ pce. 12440 .

Porcel, R. et al. Salinity stress alleviation using arbuscular mycorrhizal fungi. A review. Agronomy for Sustainable Development, v. 32, p. 181-200, 2012. DOI: 10.1007/s13593-011-0029-x.

Pospísil, F. \& Hrachová, B. Bombacopsis glabra (Pasq.) Robyns: a promising oil-bearing crop for the Socialist Republic of Vietnam. Agricultura Tropica et Subtropica, v. 20, p. 127-142, 1987.

Ribeiro, R. V. et al. Growth and leaf temperature effects on photosynthesis of sweet orange plants infected with Xylella fastidiosa. Plant Pathology, v. 53, p. 334-340, 2004. DOI: 10.1111/j.0032-0862.2004.01012.x. 
Richards, C. L. et al. Plasticity in salt tolerance traits allows for invasion of novel habitat by japanese knotweed s. 1. (Fallopia japonica and $F . \times$ bohemica, Polygonaceae). American Journal of Botany, v. 95, p. 931-942, 2008. DOI: 10.3732/ajb.2007364.

Rodrigues, C. R. F. et al. Physiological adjustment to salt stress in $R$. communis seedlings is associated with a probable mechanism of osmotic adjustment and a reduction in water lost by transpiration. Industrial Crops and Products, v. 54, p. 233-239, 2014. DOI: 10.1016/j.indcrop.2013.12.041.

Santos, M. G. et al. Caatinga, the Brazilian dry tropical forest: can it tolerate climate changes? Theoretical and Experimental Plant Physiology, v. 26, p. 83-99, 2014. DOI: 10.1007/s40626-0140008-0.

Santos, M. G. \& Pimentel, C. Daily balance of leaf sugars and amino acids as indicators of common bean (Phaseolus vulgaris L.) metabolic response and drought intensity. Physiology and Molecular Biology of Plants, v. 15, p. 23-30, 2009. DOI: 10.1007/ s12298-009-0002-1.

Santos, T. O. et al. Escarificação mecânica em sementes de chichá (Sterculia foetida L.). Revista Árvore, v. 28, p. 1-6, 2004. DOI: 10.1590/S0100-67622004000100001.

Scholander, P. F. et al. Sap pressure in vascular plants: negative hydrostatic pressure can be measured in plants. Science, v. 148, p. 339-346, 1965. DOI: 10.1126/science.148.3668.339.

Silitonga, A. S. et al. Production of biodiesel from Sterculia foetida and its process optimization. Fuel, v. 111, p. 478-484, 2013. DOI: 10.1016/j.fuel.2013.03.051.
Silva, F. C. Manual das análises químicas de solos, plantas e fertilizantes. Brasília, DF: Embrapa Informação Tecnológica, 2009. $627 \mathrm{p}$.

Souza, B. S. et al. Water relations and chlorophyll fluorescence responses of two leguminous trees from the Caatinga to different watering regimes. Acta Physiologiae Plantarum, v. 32, p. 235-244, 2010. DOI: $10.1007 / \mathrm{s} 11738-009-0394-0$.

Tester, M. \& Davenport, R. Na+ tolerance and $\mathrm{Na}+$ transport in higher plants. Annals of Botany, v. 91, p. 503-527, 2003. DOI: 10.1093/aob/mcg058.

Tezara, W. et al. Water relations and photosynthetic capacity of two species of Calotropis in a tropical semi-arid ecosystem. Annals of Botany, v. 107, p. 397-405, 2011. DOI: 10.1093/aob/mcq245.

Thomas, R. L. et al. Comparison of conventional and automated procedures for $\mathrm{N}, \mathrm{P}$ and $\mathrm{K}$ analysis of plant material using a single digestion. Agronomy Journal, v. 59, p. 240-243, 1967. DOI: 10.2134/agronj1967.00021962005900030010x.

Vipunngeun, N. \& Palanuvej, C. Fatty acids of Sterculia foetida seed oil. Journal of Health Research, v. 23, p. 157, 2009.

Wang, Y. et al. Systems dynamic modeling of a guard cell $\mathrm{Cl}^{-}$channel mutant uncovers an emergent homeostatic network regulating stomatal transpiration. Plant Physiology, v. 160, p. 1956-1967, 2012. DOI: $10.1104 /$ pp.112.207704.

Willadino, L. \& Câmara, T. R. Tolerância das plantas à salinidade: aspectos fisiológicos e bioquímicos. Enciclopédia Biosfera, v. 16, n. 11, p. 1-23, 2010.

Zhu, J-K. Regulation of ion homeostasis under salt stress. Current Opinion in Plant Biology, v. 6, p. 441- 445, 2003. DOI: 10.1016/ S1369-5266(03)00085-2. 